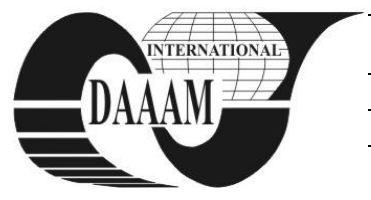

Annals of DAAAM for 2011 \& Proceedings of the 22nd International DAAAM Symposium, Volume 22, No. 1, ISSN 1726-9679 ISBN 978-3-901509-83-4, Editor B. Katalinic, Published by DAAAM International, Vienna, Austria, EU, 2011 Make Harmony between Technology and Nature, and Your Mind will Fly Free as a Bird Annals \& Proceedings of DAAAM International 2011

\title{
THE IMPLEMENTATION OF E-GOVERNMENT CONCEPT IN ROMANIA
}

\author{
SAVENCO, I[ulian] G[eorgel]; LUPSAN, G[abriela]; BOCANIALA, T[ache]; MAFTEI, J[ana]; \\ COMAN, V[arvara] L[icuta] \& GISCA, C[ristian]
}

\begin{abstract}
The emergence of new technologies has influenced the daily life of the community by shifting from a traditional society, encroached by the material elements to an information society based on knowledge. This wave of computerization that has invaded the entire globe in the recent decades has also influenced the public administration activity at both central and local level. This paper aims at presenting the concept of "e-government" (on-line government) and its implementation in Romania, a concept that resulted from the impact of computerization of services offered by the public administration in our country
\end{abstract}

Key words: public administration, e-governance, information technology, governance

\section{INTRODUCTION}

The technological revolution that marked the last decades has led to the gradual awareness of the huge potential that the computer offers to the public administration, along with the need to find a fair relation between the costs that the computerization involve and its results (Alexandru, 2004). This new tool has proven particularly useful for the administration officials. Subsequently, the astonishing development of the Internet has led to an unprecedented diversification of activities. If originally it was used as a simple way to inform people, it has subsequently become an effective method of communication The increased demand for public services and the high costs of staff have determined throughout the world to fundamentally change the way they interact with citizens, a change that was approved by the almost unanimous adoption of the new features offered by Web 2.0 technology. Although most countries provide electronic administrative services, it does not mean that there is a unified model applicable at European or global level. Each state has its own strategy for implementing these services. This change, which has penetrated the public administration structures, has resulted in the subsequent implementation of new concepts such as e-government, e-health, e-legal, e-democracy, e-auction, e-learning (Negrut et al., 2010) etc. Our concerns, in this paper, refer only to the legal issues that arise in the implementation process of e-governance concept in our country.

\section{THE ACTUAL SIZE OF E-GOVERNMENT CONCEPT}

In a concise expression, the concept of e-government is the use of technology to improve the access to administration services, distributing them to citizens and business environment. This concept has the power to create a new method by which all public organizations will be able to deliver in a modern, integrated and seamless way their services to the public. The relationship is not just one-way "us-versus-them", but rather aims at building a partnership between governors and citizens. (Silcock, 2001) E-governance is seen as an innovation, a technological change of the link between governors and citizens, created for improving the services delivered to citizens, for increasing their satisfaction, preventing the decline of public confidence in governors and why not reversing this tendency, leading them towards increasing the public confidence in governors. (Morgenson et al., 2011) According to the Romanian governors, by e-government, the officials try to revolutionize the way in which every citizen interacts with public administration in Romania. The www.e-guvernare.ro portal opens a path that will end with the complete reform of public administration, so that it can actually be put at the service of every citizen. The development of this single way of accessing the services and information of central and local administration institutions marks the beginning of "inquiry office reform", a major program according to which the Romanian Government wants to promote transparency, to make the administration more efficient by reducing costs and bureaucracy, ensuring broad accessibility to public information and services, regardless of time and place, preventing and fighting against corruption through electronic means (https://mica.e-guvernare.ro). As for us, we consider that under the conditions of a proper implementation, the concept of egovernment could be the most modern instrument of harmonization of the relations between the public administration and citizens, because it allows the government to be in a permanent link with its citizens and to adapt their services according to their needs, thus aligning with the EU standards.

\section{THE IMPLEMENTATION OF E- GOVERNMENT CONCEPT IN ROMANIA}

Achieving and implementing the e-government platform is not possible without a firm strategy in line with the assumption of an adequate legal framework, since the information society requires a close liaison between the technical and legal domain. For the successful implementation of e-governance concept it is necessary to define a consistent architecture of applications and a predefined set of generic services and tools for further developing, implementing and managing the applications. This architecture should be updated in order to ensure the correspondence between the user requirements and the emerging new technologies. (Colesca, 2002) Thus, in 2003 it was founded the National Electronic System (NES) created according to Law no. 161/2003 regarding some measures to ensure the transparency in the exercise of public dignities, public functions and in business environment, preventing and punishing corruption, accessible on the Internet at www.e-guvernare.ro, a public utility system that has as main objective the access to public information and providing public services to legal and natural persons. Unlike Romania, where the implementation of this concept was done very late in other countries, like Britain, the foundations of e-governance (understood as an established connection between government and citizens through technology), there have been implemented since the middle of last century, since the first computers 
entered large transaction processing departments (such as the Post Office) in the 1950s and then exploded with the advent of the Internet which has enabled the possibility of a two-way direct contact with the citizens. (Margetts, 2006) Although it has begun in 2003, the implementation of e-government system is not currently completed in Romania. Providing public services through the National Electronic System was to be achieved gradually, under the following steps: a) the publication by electronic means of information of public interest; b) the one-way interaction; c) two-way interaction; d) making payments through electronic means payment. Although theoretically these steps have been taken by all public authorities, their practical results are still yet to come. Thus, although the law stipulates the obligation of all public administration authorities to register and use the NES, there are still administrations that have not complied with these provisions. In our opinion, this is due to the lack of penalties for the leaders of public administration authorities which are not registered or are not using NES, namely the e-guvernare.ro portal. According to the legal regulations, the basic principles of providing public information and services by electronic means are: a) transparency in providing public information and services, b) equal access, without discrimination, to public information and services, c) efficient use of public funds; d) confidentiality, that is to guarantee the secrecy of personal data; e) ensuring the availability of information and public services.

However experience has shown that there are major shortcomings in implementing the e-government system, especially with regard to equal access to public information.

There are certain social groups that cannot benefit from the portal www.e-guvernare.ro due to poverty (e.g. gipsy population), the low level of IT knowledge (the population in the rural environment and elderly people whose knowledge of IT is limited or even nonexistent); it also failed to create versions of e-government portal in the languages of the minorities, although the law grants the right to the national minorities which cover over $20 \%$ of the inhabitants in an administrative territorial unit to use their language in the relations with local government authorities (e.g. the Hungarian population). A positive aspect in the implementation of e-government process we believe that is the "liberalization" of the electronic signature. Granting the right to issue digital certificates to companies has determined the number of holders of such certificate to increase due to their aggressive campaigns, something that the state authorities would not have been able to achieve.

\section{OBSTACLES THAT OCCUR IN THE E-GOVERNANCE IMPLEMENTATION PROCESS}

The implementation of a new concept such as e-governance has encountered, from the outset, a series of obstacles which we believe that can be categorized into four broad categories: regulatory, financial, technological and human, being linked and interdependent. Regulatory barriers refer to the difficulty with which it has been adopted or applied the legislation that deals with the legal framework required to implement the e-governance system in Romania. In the case of digital signature legislation in addition to "ordinary" barriers (recognition, adoption, etc.) there are included religious criticism as it was considered "the last yoke that the system puts to the human being", "a society of robots", "the human decline to person, to names, to numbers." (***, 2011) The financial obstacles concern the lack of resources necessary for each administration in order to implement the e-government system, the budgetary allocations for this area is very small or nonexistent. A solution in this case would be, in our view, an increase in the access degree to the EU funds allocated for the e-governance. The technological obstacles relate to the compatibility of various systems within the administrations in order to create a common basis, to the absence of mandatory standards applicable to all administrations. We consider that the human obstacles fall into two broad categories. First of all it is the need for an increased number of IT specialists, able to meet the new tasks arising from the computerization of the administration. Computer science compels us to rethink the rules, laws, it modifies the conditions of employment of officials, which entail a reformulation of the structures. (Alexandru, 2004) Secondly there is a cultural barrier between citizens and technology that leads to the restriction of communication between citizens and administration. Many people do not have the knowledge necessary to work with a computer, which leads them far from e-government system and letting them remain within their traditional services. These obstacles delay the implementation of the e-government services or they even make impossible their implementation.

We believe it is necessary to eliminate these obstacles in order to achieve the necessary framework for e-government implementation process.

\section{CONCLUSION}

This article has identified a series of inconsistencies and legal obstacles that arise in the implementation of the egovernance concept, being also the basis of a future study that will look further into these issues and propose solutions to eliminate them, thus helping the fluidization process of egovernance in Romania, a decisive factor in the communication between administration and citizens, as through e-government there is a permanent link between government and citizens; they have access to administration services regardless of where they are located, corruption is reduced by eliminating the physical link between citizens and officials, it is reduced the administration operating costs and the public administration activity becomes more efficient. Currently the old bureaucracy makes it difficult to interact and to face the great demands of public services, which is why we believe that the implementation of e-government in Romania must continue until the expected results are obtained.

\section{REFERENCES}

Alexandru, I. (2004). Dreptul şi managementul - Dihotomie sau complementaritate. Impactul informatizării, All Beck Publishing House, ISBN 973-655-480-5, Bucharest

Colesca, S.E. (2002). Internet în administrația publică, Economică Publishing House, ISBN 973-590-733-X, Bucharest

Margetts, H. (2006). E-Government in Britain-A Decade On. Parliamentary Affairs, Vol. 59, No. 2, (April 2006) pp. 250-265, Online ISSN 1460-2482 - Print ISSN 0031-2290

Morgeson III F.V., VanAmburg D., Mithas S. (2011). Misplaced Trust? Exploring the Structure of the EGovernment-Citizen Trust Relationship. Journal of Public Administration Research and Theory, Volume 21, Issue 2, pp. 257-283, Online ISSN 1477-9803 - Print ISSN 10531858

Negrut, V.; Costache, M. P.; Negrut, A.; Maftei, J.; Coman, V. L. \& Matei, D. (2010). Current Dimensions of Distance Learning, Annals of DAAAM for 2010 \& Proceedings of the $21 \mathrm{st}$ International DAAAM Symposium, 20-23rd October 2010, Zadar, Croatia, ISSN 1726-9679, ISBN 9783-901509-73-5, Katalinic, B. (Ed.), pp. 1263-1264, Published by DAAAM International Vienna, Vienna

Silcock, R. (2001). What is e-Government? Parliamentary Affairs, Volume 54, Issue 1, pp. 88-101, Online ISSN 14602482 - Print ISSN 0031-2290

*** https://mica.e-guvernare.ro, Accessed on: 2011-05-25.

*** (2011) http://atitudini.com/interviu-cu-parintele-justinjugul-erei-electronice, Accessed on: 2011-05-25 